\title{
Stability of freeze-dried plasma prepared from patients on oral anticoagulants
}

\author{
MILICA BROZOVIĆ, D. J. HOWARTH, L. P. van HALEM VISSER, \\ AND E. A. LOELIGER \\ From the National Institute for Biological Standards and Control, London, and Academisch Ziekenhuis, \\ Leiden
}

SYNOPSIS The suitability of freeze-dried plasmas from patients on oral anticoagulants to serve as reference material in the calibration of thromboplastins used in the control of oral anticoagulant treatment was assessed in two centres. One pooled normal plasma and four pooled plasmas from patients at different levels of anticoagulation were collected into HEPES-citrate containing Trasylol. The plasmas, in $1 \mathrm{ml}$ volumes, were freeze dried in siliconized ampoules under the optimal conditions used for biological standards. Small aliquots of the same plasmas were stored at $-70^{\circ} \mathrm{C}$.

Five different thromboplastins were used to carry out the tests on these plasmas. There was little difference in the clotting times obtained with five reference thromboplastins (two human, two rabbit, and one bovine reagent) on frozen and freeze-dried plasma, if the latter was tested immediately after complete reconstitution or within six hours of reconstitution if kept at $+4^{\circ} \mathrm{C}$. Reconstituted plasmas showed a marked shortening of clotting times when stored at 22 and $37^{\circ} \mathrm{C}$ if thromboplastins sensitive to activation of factor VII were used. In contrast, when thromboplastins sensitive to factor $\mathrm{V}$ were used, prothrombin times in plasmas stored at 22 and $37^{\circ} \mathrm{C}$ became prolonged due to the loss of factor V.

Freeze-dried plasmas from patients on oral anticoagulants can be used to calibrate thromboplastins, provided they are used immediately after complete reconstitution or kept at $+4^{\circ} \mathrm{C}$ for use within four to six hours of reconstitution.

The standardization of the one-stage prothrombin time has been extensively studied and frequently reviewed (Biggs, 1965, 1969; Biggs and Denson, 1966; Biggs and Denson, 1967a, b; van Horn, 1968; Denson, 1969; Miale and LaFond, 1969; Loeliger and Hemker, 1970; Loeliger, Meuwisse-Braun, Buiterdijk, Veltkamp, and Hemker, 1970; Poller, 1970a and b; Zucker, Cathey, and West, 1970; Poller, Thomson, and Alderson, 1971 ; Loeliger, 1972; Miale and Kent, 1973). A number of different schemes for defining the therapeutic range and for standardizing the prothrombin time test are used in different countries. All these schemes are based on the use of one of the two types of reference materials, thromboplastins (Denson, 1966, 1967; Bangham, Biggs, Brozović, and Denson, 1970, 1973; Poller, 1970b, 1971 ; Biggs and Bangham, 1971) or plasma (Miale and LaFond, 1969; Miale and Kent, 1972; (Bangham, Biggs, Brozović, and Denson, 1973).

Received for publication 31 July 1973.
The suitability of thromboplastins to serve as longterm standards has been studied and documented (Denson, 1966, 1967; Poller, 1970b, 1971 ; Bangham et al, 1970, 1973; Biggs and Bangham, 1971). A similar but much larger international collaborative study to investigate the use of reference plasmas is being organized. Two types of reference plasmas will be studied: first freeze-dried plasmas prepared from blood of patients on oral anticoagulants and secondly freeze-dried artificially prepared abnormal plasmas designed to mimic the situation in patients on oral anticoagulants. As a preliminary to this international trial we have studied the suitability of freeze-dried plasma collected from patients to serve as reference material and the results are reported here.

\section{Materials}

PLASMAS

Five plasmas were studied, one normal and four plasmas collected from patients on oral anticoagulants. 
Plasma pool $72 / 411$ consisted of plasma from 20 normal individuals, 10 men and 10 women; $18 \mathrm{ml}$ of blood was collected into $2 \mathrm{ml}$ HEPES-citrate solution in plastic containers.

Plasma pools 72/425, 72/427, 72/429, 72/431 consisted each of plasma from 30 patients stabilized on long-term anticoagulants. From each patient $4.5 \mathrm{ml}$ of plasma was collected into $0.5 \mathrm{ml}$ HEPES (N-2-hydroxyethylpiperazine- $\mathrm{N}^{1}$-2-ethanesulphonic acid) citrate solution in plastic containers.

The HEPES citrate solution was made up in the following manner:

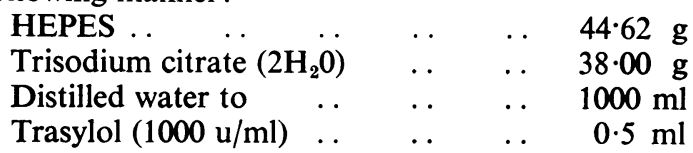

Individual samples were centrifuged at $3000 \mathrm{rpm}$ for $10 \mathrm{~min}$ at room temperature, the plasmas separated and pooled. The pools were centrifuged in plastic containers at $20000 \mathrm{~g}$ at $4^{\circ} \mathrm{C}$ for 30 minutes. In order to prevent bacterial growth $1 \mathrm{ml}$ of $10 \%$ $\mathrm{NaN}_{3}$ was added per litre of plasma.

The plasmas were distributed in $1 \mathrm{ml}$ volumes into siliconized glass ampoules: 20 ampoules from each pool were sealed and stored frozen at $-70^{\circ} \mathrm{C}$. The remainder were freeze-dried under optimal conditions for biological standards. Twenty ampoules from each freeze-dried pool were stored at $37^{\circ} \mathrm{C}$ whereas the bulk of the ampoules was stored at $-20^{\circ} \mathrm{C}$.

\section{THROMBOPLASTINS}

1 Thromboplastin 67/40 human, research standard $A$ This is a specially prepared freeze-dried human brain preparation containing bovine fibrinogen and factor V. It is reconstituted with $2.0 \mathrm{ml}$ of $3.2 \mathrm{mM} \mathrm{CaCl}_{2}$ and used in $0.4 \mathrm{ml}$ volumes with $0.05 \mathrm{ml}$ of plasma.

\section{Thromboplastin 69/223, human plain, MRC reagent}

This thromboplastin is a batch of freeze-dried Manchester reagent. It is reconstituted with $2 \mathrm{ml}$ distilled water and used in $0.1 \mathrm{ml}$ volumes with $0.1 \mathrm{ml}$ of plasma and $0.1 \mathrm{ml}$ of $25 \mathrm{mM} \mathrm{CaCl}_{2}$.

\section{Thromboplastin 68/434 bovine, MRC reagent}

This is a specially prepared batch of Thrombotest, bovine brain reagent with bovine factor $\mathrm{V}$ and fibrinogen. It is reconstituted with $2.2 \mathrm{ml}$ of $3.2 \mathrm{mM}$ $\mathrm{CaCl}_{2}$ and used in $0.4 \mathrm{ml}$ volumes with $0.05 \mathrm{ml}$ plasma.

\section{Thromboplastin $70 / 115$, rabbit MRC reagent}

This is a specially prepared batch of Normotest, rabbit brain reagent with bovine factor $\mathrm{V}$ and fibrinogen. It is reconstituted with $2.2 \mathrm{ml}$ distilled water and used in $0.25 \mathrm{ml}$ volumes with $0.01 \mathrm{ml}$ plasma.

5 Thromboplastin $70 / 178$, rabbit plain, $M R C$ reagent This is a freeze-dried rabbit brain suspension. It is reconstituted with $1 \mathrm{ml}$ distilled water and used in $0.1 \mathrm{ml}$ volumes with 0.1 plasma and $0.1 \mathrm{ml} 25 \mathrm{mM}$ $\mathrm{CaCl}_{2}$.

\section{Methods}

The tests were performed at the Academisch Ziekenhuis in Leiden and at the National Institute for Biological Standards and Control in London. Both laboratories performed prothrombin times using five different thromboplastins on frozen and on freeze-dried plasmas. The clotting times on freezedried plasma were performed immediately after reconstitution, four to six hours after reconstitution in samples stored at $+4^{\circ} \mathrm{C},+20^{\circ} \mathrm{C}$, and $+37^{\circ} \mathrm{C}$ during this time, and 24 hours after reconstitution on samples stored at these temperatures. In addition, prothrombin times were carried out on freeze-dried plasma samples stored at $37^{\circ} \mathrm{C}$ for two months (table I).

The levels of factors VII, IX, and X and prothrome bin were estimated by both laboratories in froze samples and in freeze-dried samples stored at $-20^{\circ} \mathrm{C}$ and $+37^{\circ} \mathrm{C}$ for two months, using the same freezedried reference plasma.

The behaviour of factor VII in reconstituted freezedried plasma was followed for 24 hours in one laboratory. Factor VII levels were measured immediately after reconstitution and after five, 10 , 30 , and 60 minutes, as well as after six hours and 24 hours.

The tests with five thromboplastins were done manually, whereas the factor assays were carried out using Depex coagulometers.

\section{Results}

COMPARISON OF PROTHROMBIN TIMES AND PROTHROMBIN TIME RATIOS ON FROZEN AND FREEZE-DRIED PLASMA AFTER

RECONSTITUTION

There was little or no difference in clotting times obtained with frozen plasma when compared to those obtained with freeze-dried plasma; this was reflected in clotting time ratios which were virtually the same for frozen and freeze-dried abnormal plasmas. This is shown in tables I and II using as illustration the results obtained with thromboplastin $67 / 40$, research standard A, and in table III showing the results of the clotting times of normal plasma with all five thromboplastins. 


\begin{tabular}{|c|c|c|c|c|c|c|c|c|c|c|}
\hline \multirow[t]{4}{*}{ Plasma } & \multicolumn{10}{|c|}{ Plasma Pool } \\
\hline & \multicolumn{2}{|c|}{ Normal } & \multicolumn{2}{|c|}{ Abnormal 1} & \multicolumn{2}{|c|}{ Abnormal 2} & \multicolumn{2}{|c|}{ Abnormal 3} & \multicolumn{2}{|c|}{ Abnormal 4} \\
\hline & \multicolumn{4}{|c|}{ Laboratory } & & & & & & \\
\hline & 1 & 2 & $I$ & 2 & 1 & 2 & $I$ & 2 & 1 & 2 \\
\hline $\begin{array}{l}\text { Clotting time } \\
\text { Frozen (mean) } \\
\text { Freeze dried }\end{array}$ & $\begin{array}{l}18 \cdot 5 \\
18 \cdot 5\end{array}$ & $\begin{array}{l}19 \cdot 5 \\
19 \cdot 5\end{array}$ & $\begin{array}{l}33 \cdot 5 \\
34 \cdot 0\end{array}$ & $\begin{array}{l}34 \cdot 7 \\
35 \cdot 9\end{array}$ & $\begin{array}{l}44.5 \\
45.0\end{array}$ & $\begin{array}{l}47.0 \\
45.0\end{array}$ & $\begin{array}{l}51 \cdot 5 \\
52 \cdot 5\end{array}$ & $\begin{array}{l}53 \cdot 5 \\
55.9\end{array}$ & $\begin{array}{l}58 \cdot 5 \\
58 \cdot 5\end{array}$ & $\begin{array}{l}61 \cdot 8 \\
60 \cdot 7\end{array}$ \\
\hline
\end{tabular}

Table I Clotting times with thromboplastin 67/40 human, research standard A

\begin{tabular}{|c|c|c|c|c|c|c|c|c|}
\hline \multirow[t]{4}{*}{ Plasma } & \multicolumn{8}{|c|}{ Plasma Pool } \\
\hline & \multicolumn{2}{|c|}{ Abnormal 1} & \multicolumn{2}{|c|}{ Abnormal 2} & \multicolumn{2}{|c|}{ Abnormal 3} & \multicolumn{2}{|c|}{ Abnormal 4} \\
\hline & \multicolumn{4}{|c|}{ Laboratory } & & & & \\
\hline & 1 & 2 & 1 & 2 & 1 & 2 & 1 & 2 \\
\hline $\begin{array}{l}\text { Clotting time (fresh) } \\
\text { Clotting time (freeze dried) }\end{array}$ & $\begin{array}{l}1 \cdot 81 \\
1 \cdot 83\end{array}$ & $\begin{array}{l}1 \cdot 79 \\
1 \cdot 87\end{array}$ & $\begin{array}{l}2 \cdot 40 \\
2 \cdot 43\end{array}$ & $\begin{array}{l}2 \cdot 33 \\
2 \cdot 48\end{array}$ & $\begin{array}{l}2 \cdot 78 \\
2 \cdot 83\end{array}$ & $\begin{array}{l}2 \cdot 78 \\
2 \cdot 92\end{array}$ & $\begin{array}{l}3 \cdot 16 \\
3 \cdot 16\end{array}$ & $\begin{array}{l}3 \cdot 14 \\
3 \cdot 23\end{array}$ \\
\hline
\end{tabular}

Table II Clotting time ratios with thromboplastin $67 / 40$ human research standard $A$

\begin{tabular}{|c|c|c|c|c|}
\hline \multirow[t]{4}{*}{ Thromboplastin } & \multicolumn{4}{|c|}{ Laboratory } \\
\hline & \multicolumn{2}{|l|}{1} & \multicolumn{2}{|l|}{2} \\
\hline & \multicolumn{4}{|l|}{ Plasma } \\
\hline & Frozen & $\begin{array}{l}\text { Freeze } \\
\text { Dried }\end{array}$ & Frozen & $\begin{array}{l}\text { Freeze } \\
\text { Dried }\end{array}$ \\
\hline $\begin{array}{l}67 / 40 \\
69 / 223 \\
68 / 434 \\
70 / 115 \\
70 / 178\end{array}$ & $\begin{array}{l}18 \cdot 5 \\
13 \cdot 5 \\
36 \cdot 5 \\
27 \cdot 5 \\
14 \cdot 0\end{array}$ & $\begin{array}{l}18.5 \\
13 \cdot 5 \\
37 \cdot 0 \\
27.0 \\
14.5\end{array}$ & $\begin{array}{l}19 \cdot 1 \\
14 \cdot 7 \\
39 \cdot 9 \\
23 \cdot 7 \\
15 \cdot 1\end{array}$ & $\begin{array}{l}19 \cdot 3 \\
13 \cdot 3 \\
41 \cdot 0 \\
23 \cdot 0 \\
15 \cdot 3\end{array}$ \\
\hline
\end{tabular}

Table III Prothrombin times of normal plasma with different thromboplastins

CLOTTING TIMES AND CLOTTING TIME RATIOS IN RECONSTITUTED FREEZE-DRIED PLASMA STORED AT DIFFERENT TEMPERATURES

The reconstituted plasmas were stored at +4 , 22 , and $37^{\circ} \mathrm{C}$ and the prothrombin times performed with different thromboplastins after four to six hours and 24 hours of storage.

Plasmas stored at $+4^{\circ} \mathrm{C}$

There was virtually no change in clotting times or clotting time ratios of plasmas stored at $4^{\circ}$ during the first four to six hours. After 24 hours of storage the clotting times obtained with thromboplastins $67 / 40,68 / 434$, and $70 / 115$ were occasionally shorter than immediately after reconstitution, although the clotting ratios remained similar to the initial value. The.clotting times and clotting time ratios obtained with thromboplastins $69 / 223$ and $70 / 178$ remained unchanged (figs 1 and 2).

Plasma stored at $+20^{\circ} \mathrm{C}$

Clotting times obtained with thromboplastins $69 / 223,70 / 178$, and $70 / 115$ showed very slight prolongation, whereas with thromboplastins $67 / 40$, and in particular $68 / 434$, a marked shortening of clotting times was evident. After 24 hours at room temperature these effects became more pronounced. The prothrombin time ratios obtained with thromboplastins $67 / 40,68 / 434$, and $70 / 115$ remained very similar to those of freshly reconstituted plasma. With thromboplastin 70/178, and in particular $69 / 223$, the prothrombin time ratios were variable, but usually lower than in the freshly reconstituted plasma. This is illustrated in figures 3 and 4.

\section{Plasma stored at $+37^{\circ} \mathrm{C}$}

There was a marked prolongation of clotting times with thromboplastins $69 / 223$ and 70/178 after four to six hours' incubation, becoming more marked after 24 hours. The clotting times were only slightly prolonged in tests with thromboplastin $70 / 115$. In contrast, the clotting times invariably shortened with thromboplastin $67 / 40$ and in particular with thromboplastin 68/434 (see figs 5 and 6). Nevertheless, the prothrombin time ratios obtained with thromboplastins $67 / 40,68 / 434$, and 70/115 remained unaffected by the storage of plasma at $37^{\circ} \mathrm{C}$ for up to 24 hours. The ratios obtained with thromboplastins 69/223 and 70/178 varied and were often lower than before incubation. 


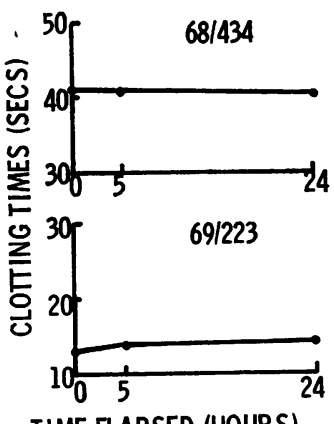

TIME ELAPSED (HOURS)

Fig 1

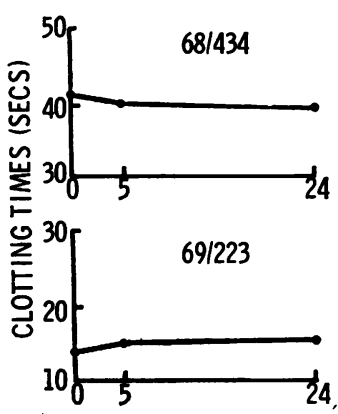

TIME ELAPSED (HOURS)

Fig 3

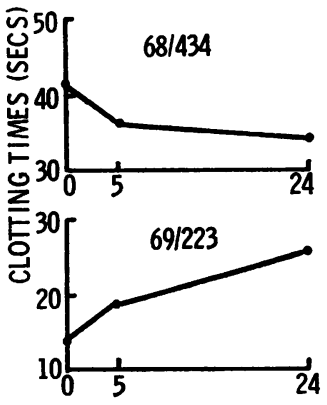

TIME ELAPSED (HOURS)

Fig 5

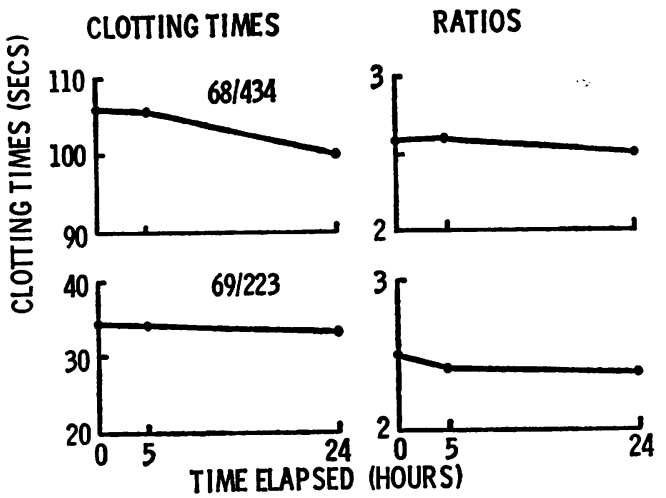

Fig 2

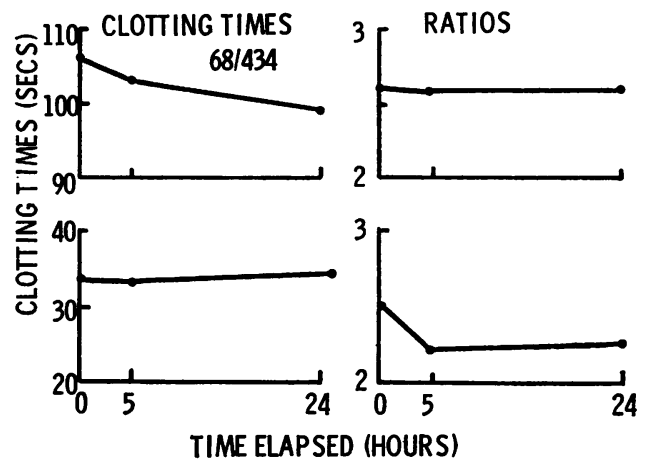

Fig 4

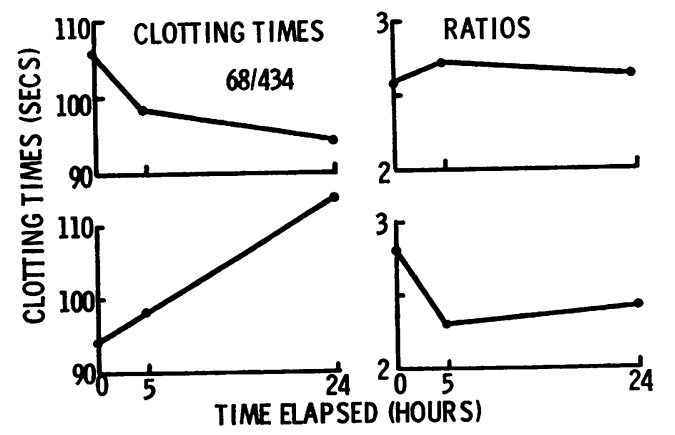

Fig 6
Fig 1 Behaviour of reconstituted plasma 72/411 (normal) at $+4^{\circ}$.

Fig 2 Behaviour of reconstituted plasma $72 / 428$ (abnormal 3) at $+4^{\circ} \mathrm{C}$.

Fig 3 Behaviour of reconstituted plasma $72 / 411$ (normal) at $+20^{\circ} \mathrm{C}$.

Fig 4 Behaviour of reconstituted plasma $72 / 428 \overline{\bar{c}}$ (abnormal 3) at $+20^{\circ} \mathrm{C}$.

Fig 5 Behaviour of reconstituted plasma $72 / 411$ (normal) at $37^{\circ} \mathrm{C}$.

Fig 6 Behaviour of reconstituted plasma 72/428 (abnormal 3) at $37^{\circ} \mathrm{C}$.
BEHAVIOUR OF FACTOR VII IN RECONSTITUTED FREEZE-DRIED PLASMA

As the cold-promoted shortening of the thrombotest time is due to the activation of factor VII (Gjønnaess, 1972), the behaviour of factor VII was investigated in reconstituted freeze-dried plasma stored in plastic containers. The results are shown in figure 7. At room temperature, and particularly at $37^{\circ} \mathrm{C}$, there was a rapid activation of factor VII. There was no increase in factor VII activity at $4^{\circ} \mathrm{C}$. 


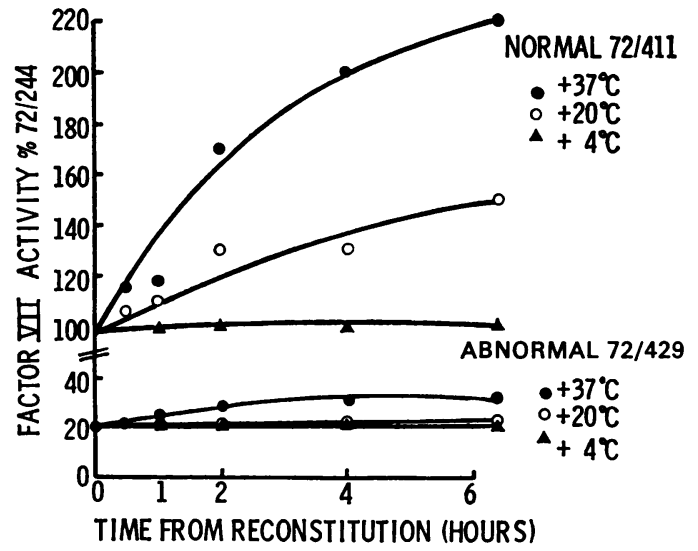

Fig 7 Effect of temperature on factor VII activity in reconstituted plasma $72 / 411$ (normal) and 72/429 (abnormal 3).
LEVELS OF PROTHROMBIN AND FACTORS VII, IX, AND X IN FROZEN AND FREEZEDRIED PLASMA

The levels of the four vitamin-K-dependent factors were measured in frozen plasma and in freezedried plasma stored at -20 and $+37^{\circ} \mathrm{C}$ for two months, as shown in tables IV, V, VI, and VII. All four factors showed slight decrease in activity in samples stored at $37^{\circ} \mathrm{C}$; this fall was most pronounced for factor IX. The two laboratories, each using different methods and substrate plasmas, were in good agreement except for factor VII, where laboratory 1 measured a slight fall in factor VII activity on storage, whereas laboratory 2 detected a slight rise.

The prothrombin times of plasmas stored at $+37^{\circ} \mathrm{C}$ for two months were invariably slightly longer than those with plasma stored at $-20^{\circ} \mathrm{C}$, as shown in table VIII.

\begin{tabular}{|c|c|c|c|c|c|c|c|c|c|c|}
\hline \multirow[t]{4}{*}{ Plasma } & \multicolumn{10}{|c|}{ Plasma Pool } \\
\hline & \multicolumn{2}{|c|}{ Normal 72/411 } & \multicolumn{2}{|c|}{ Abnormal $72 / 425$} & \multicolumn{2}{|c|}{ Abnormal 72/427 } & \multicolumn{2}{|c|}{ Abnormal 72/429 } & \multicolumn{2}{|c|}{ Abnormal 72/431 } \\
\hline & \multicolumn{4}{|c|}{ Laboratory } & & & & & & \\
\hline & $I$ & 2 & 1 & 2 & 1 & 2 & 1 & 2 & 1 & 2 \\
\hline \multirow{3}{*}{$\begin{array}{l}\text { Frozen } \\
\text { Freeze dried } \\
\left(-20^{\circ} \mathrm{C}\right) \\
\text { Freeze dried } \\
\left(+37^{\circ} \mathrm{C}\right)\end{array}$} & 114 & 100 & 49 & 47 & 31 & 39 & 24 & 35 & 20 & 28 \\
\hline & 109 & 120 & 44 & 47 & 28 & 29 & 24 & 26 & 19 & 24 \\
\hline & 100 & 100 & 41 & 47 & 27 & 40 & 21 & 35 & 19 & 26 \\
\hline
\end{tabular}

Table IV Prothrombin

\begin{tabular}{|c|c|c|c|c|c|c|c|c|c|c|}
\hline & \multicolumn{10}{|c|}{ Plasma } \\
\hline & \multicolumn{2}{|c|}{ Normal $72 / 411$} & \multicolumn{2}{|c|}{ Abnormal 72/425 } & \multicolumn{2}{|c|}{ Abnormal 72/427 } & \multicolumn{2}{|c|}{ Abnormal $72 / 429$} & \multicolumn{2}{|c|}{ Abnormal $72 / 431$} \\
\hline & \multicolumn{4}{|c|}{ Laboratory } & & & & & & \\
\hline & 1 & 2 & 1 & 2 & 1 & 2 & 1 & 2 & 1 & 2 \\
\hline $\begin{array}{l}\text { Frozen } \\
\text { Freeze dried }\end{array}$ & 105 & 100 & 43 & 25 & 27 & 20 & 21 & 19 & 20 & 15 \\
\hline $\begin{array}{l}\left(-20^{\circ} \mathrm{C}\right) \\
\text { Freeze dried }\left(37^{\circ} \mathrm{C}\right)\end{array}$ & $\begin{array}{r}100 \\
84\end{array}$ & $\begin{array}{r}95 \\
102\end{array}$ & $\begin{array}{l}35 \\
33\end{array}$ & $\begin{array}{l}31 \\
39\end{array}$ & $\begin{array}{l}24 \\
24\end{array}$ & $\begin{array}{l}27 \\
32\end{array}$ & $\begin{array}{l}22 \\
20\end{array}$ & $\begin{array}{l}22 \\
29\end{array}$ & $\begin{array}{l}19 \\
18\end{array}$ & $\begin{array}{l}18 \\
22\end{array}$ \\
\hline
\end{tabular}

Table V Factor VII

\begin{tabular}{|c|c|c|c|c|c|c|c|c|c|c|}
\hline & \multicolumn{10}{|c|}{ Plasma } \\
\hline & \multirow{2}{*}{\multicolumn{2}{|c|}{$\begin{array}{l}\text { Normal }(72 / 411) \\
\text { Laboratory }\end{array}$}} & \multicolumn{2}{|c|}{ Abnormal (72/425) } & \multicolumn{2}{|c|}{ Abnormal (72/427) } & \multicolumn{2}{|c|}{ Abnormal (72/429) } & \multicolumn{2}{|c|}{ Abnormal (72/431) } \\
\hline & & & & & & & & & & \\
\hline & 1 & 2 & 1 & 2 & 1 & 2 & 1 & 2 & 1 & 2 \\
\hline $\begin{array}{l}\text { Frozen } \\
\text { Freeze dried }\left(-20^{\circ} \mathrm{C}\right) \\
\text { Freeze dried }\left(37^{\circ} \mathrm{C}\right)\end{array}$ & $\begin{array}{r}101 \\
109 \\
90\end{array}$ & $\begin{array}{r}100 \\
108 \\
82\end{array}$ & $\begin{array}{l}76 \\
60 \\
39\end{array}$ & $\begin{array}{l}64 \\
76 \\
30\end{array}$ & $\begin{array}{l}53 \\
41 \\
30\end{array}$ & $\begin{array}{l}52 \\
48 \\
40\end{array}$ & $\begin{array}{l}41 \\
29 \\
26\end{array}$ & $\begin{array}{l}45 \\
38 \\
40\end{array}$ & $\begin{array}{l}32 \\
24 \\
22\end{array}$ & $\begin{array}{l}40 \\
24 \\
21\end{array}$ \\
\hline
\end{tabular}


Table VII Factor $X$

\begin{tabular}{|c|c|c|c|c|}
\hline \multirow[t]{4}{*}{ Thromboplastin } & \multicolumn{4}{|c|}{ Laboratory } \\
\hline & \multicolumn{2}{|l|}{$I$} & \multicolumn{2}{|l|}{2} \\
\hline & \multicolumn{4}{|c|}{ Plasma Stored at } \\
\hline & $-20 \mathrm{C}$ & $37^{\circ} \mathrm{C}$ & $-20 \mathrm{C}$ & $37^{\circ} \mathrm{C}$ \\
\hline $67 / 40$ & 18.5 & $19 \cdot 0$ & $19 \cdot 1$ & $19 \cdot 6$ \\
\hline $69 / 223$ & 13.5 & 14.6 & 14.7 & 14.5 \\
\hline $68 / 434$ & $36 \cdot 5$ & 40.0 & $41 \cdot 0$ & $41 \cdot 5$ \\
\hline $70 / 115$ & $27 \cdot 5$ & $28 \cdot 5$ & $23 \cdot 0$ & $24 \cdot 6$ \\
\hline $70 / 178$ & $14 \cdot 0$ & $15 \cdot 7$ & $15 \cdot 1$ & $16 \cdot 1$ \\
\hline
\end{tabular}

Table VIII Prothrombin times of normal plasma with different thromboplastins

\section{Discussion}

It is evident from the results reported here that freeze-dried plasma collected from patients on oral anticoagulants can be used to calibrate thromboplastins, as the calibration of thromboplastins makes use of prothrombin time ratios which remain unaffected by storage of freeze-dried or reconstituted plasma.

Standardization procedures that depend on absolute clotting times are open to many disadvantages. First, as shown in tables I, II, III, and VIII, two laboratories using identical thromboplastins, identical plasmas, and identical technique did not record identical clotting times.

Secondly, the prothrombin times of reconstituted plasma stored at room temperature and $37^{\circ} \mathrm{C}$ showed marked prolongation of clotting time (with thromboplastins 69/223 and 70/178) due to the deterioration of factor $\mathrm{V}$, or alternatively marked shortening of clotting times (with thromboplastins 68/434) due to the activation of factor VII.

Thirdly, the preliminary accelerated degradation studies showed that the prothrombin times of freezedried plasma were invariably prolonged. This instability of freeze-dried plasma makes it unsuitable as a basis for standardization relying on clotting times.

The activation of factor VII, in Trasylol-treated, freeze-dried plasma follows the pattern already described (Brozović and Gurd, 1972) for plasma with added soya bean trypsin inhibitor: the activa- tion is most marked at $37 \mathrm{C}$, whereas little activation occurs at $4{ }^{\circ} \mathrm{C}$. This behaviour of factor VII makes the immediate use of freeze-dried plasma a prerogative for comparable and successful tests.

The limited degradation studies performed in this study are in good agreement with previously reported results on the stability of vitamin-Kdependent factors (Brozović, Gurd, Robertson, and Bangham, 1971a, b). It is of interest that factor IX appears to be the least stable of the four factors investigated.

\section{References}

Bangham, D. R., Biggs, R., Brozović, M., and Denson, K. W. E (1970). Draft report of a collaborative study of two thromboe plastins (including the use of common abnormal plasma Thrombos. Diathes. haemorrh. (Stuttg.),Suppl. 40, pp. 341-35

Bangham, D. R., Biggs, R., Brozović, M., and Denson, K. W. (1973). Calibration of five different thromboplastins usin fresh and freeze dried plasma. Thrombos. Diathes. haemorrh. (Stuttg.), 29, pp. 228-239.

Biggs, R. (1965). Report on the standardization of one-stage prothrombin time for the control of anticoagulant therapy. Thrombos. Diathes. haemorrh. (Stuttg.), Suppl. 17, 303-330.

Biggs, R. (1969). The standardization of the prothrombin time for the control of anticoagulant therapy. Thrombos. Diathes. haemorrh. (Stuttg.), Suppl. 35, pp. 87-92.

Biggs, R., and Bangham, D. R. (1971). Standardization of the onestage prothrombin time test for the control of anticoagulant therapy: availability and use of thromboplastin reference preparations. Brit. med. J., 3, 470-471.

Biggs, R., and Denson, K. W. E. (1966). Second report on the standardization of the one-stage prothrombin time for the control of anti-coagulant therapy. Thrombos. Diathes. haemorrh. (Stuttg.), Suppl. 20, pp. 345-361.

Biggs, R., and Denson, K. W. E. (1967a). Third report on the standardization of one-stage prothrombin time for the control of anticoagulant therapy. Thrombos. Diathes. haemorrh. (Stuttg.), Suppl. 26, pp. 445-454.

Biggs, R., and Denson, K. W. E. (1967b). Standardization of the onestage prothrombin time for the control of anticoagulant therapy. Brit. med. J., 1, 84-88.

Brozović, M., Gurd, L. J., Robertson, I., and Bangham, D. R. (1971a). Factor $X$ in freeze-dried Factor VIII reference plasma. Brit. J. Haemat., 21, 201-208.

Brozović, M., and Gurd, L. J. (1972). The effect of soya bean trypsin inhibitor on kaolin induced activation of factor VII. Scand. J. Haemat., 9, 509-515.

Brozović, M., Gurd, L. J., Robertson, I., and Bangham, D. R. (1971b). Stability of prothrombin and factor VII in freeze dried plasma. J. clin. Path., 24, 690-693.

Denson, K. W. E. (1966). Criteria for a standard thromboplastin preparation. Thrombos. Diathes, haemorrh. (Stuttg.), Suppl. 20, pp.|363-376.

Denson, K. W. E. (1967). Proposed specification for a reference throm boplastin preparation for control of anticoagulant therapy using coumarin type drugs. Thrombos. Diathes. haemorrh. (Stuttg.), Suppl. 26, pp. 437-440. 
Denson, K. W. E. (1969). Fourth report on the standardization of one-stage prothrombin time for the control of anticoagulant therapy. Thrombos. Diathes. haemorrh. (Stuttg.), Suppl. 35, pp. 197-206.

Gjønnaess, H. (1972). Cold promoted activation of factor VII. In: Evidence for the existence of an activator. Thrombos. Diathes. haemorrh. (Stuttg.), 28, pp. 155-168.

van Horn, P. (1968). Quality control of prothrombin determinations normal and abnormal prothrombin activity levels. Amer. $J$. med. Technol., 34, 1.

Loeliger, E. A. (1972). Progress in the control of oral anticoagulation. Thrombos. Diathes. haemorrh. (Stuttg.), 28, pp. 109-119.

Loeliger, E. A., and Hemker, H. C. (1970). Control of long term anticoagulant treatment. Lancet, $1,894$.

Loeliger, E. A., Meuwisse-Braun, J. B., Buitendijk, F. J. J., Veltkamp, J. J., and Hemker, H. C. (1970). Laboratory control of oral anticoagulants. Definition of therapeutic range in terms of different thromboplastin preparations. Thrombos. Diathes. haemorrh. (Stuttg.), 23, pp. 569-584.
Miale, J. B., and Kent, J. W. (1972) Standardization of the therapeutic range for oral anticoagulants based on standard reference plasmas. Amer. J. clin. Path., 57, 80-88.

Miale, J. B., and LaFond, D. (1969). Prothrombin time standardization. Amer. J. clin. Path., 52, $154-160$.

Poller, L. (1970a). Prothrombin time standardization. (Letter). Amer. J. clin. Path., 54, 670-672.

Poller, L. (1970b). The British comparative thromboplastin and its quality control. Thrombos. Diathes. haemorrh. (Stuttg.), Suppl. 40, pp. 353-358.

Poller, L. (1971). The British national thromboplastin. Brit. J. Haemat., 20, 359-362.

Poller, L., Thomson, J. M., and Alderson, M. R. (1971). The British system for anticoagulant control and thrombotest. J. clin. Path., 24, 143-146.

Zucker, S., Cathey, M. H., and West, B. (1970). Preparation of quality control specimens for coagulation. Amer. J. clin. Path., 53, 924-927. 